\title{
A Note on Starfish Fungus of Anemone Stinkhorn Aseroe Rubra (Jacques Labillaridiere, 1755-1834) (Family: Phallaceae) Found in Western-Ghats of India (08ㅜㅜㅇ'17.74'N

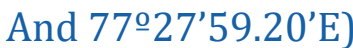

\section{Vaitheeswaran Thiruvengadam ${ }^{1 *}$ and M Anand Kumar ${ }^{2}$ \\ ${ }^{1}$ Lecturer, Department of Aquaculture, DMI St. John the Baptist University, Mangochi Campus, Republic of Malawi, Central Africa ${ }^{2}$ District Forest Officer, Machuvadi, Pudukottai District, Tamil Nadu, India}

*Corresponding Author: Vaitheeswaran Thiruvengadam, Lecturer, Department of Aquaculture, DMI St. John the Baptist University, Mangochi Campus, Republic of Malawi, Central Africa.

Received: November 06, 2019; Published: November 19, 2019

DOI: 10.31080/ASMI.2019.02.0441

Status

Aseroe rubra, commonly known as the Anemone Stinkhorn or Starfish Fungus. This species found in tropical and subtropical area. According to Jacques Labillardiere (1755 - 1834) was coined and published a scientific description of this species in 1800 , is called as Statfish Stinkhorn of Aseroe rubra. A member of the D'Entrecasteaux expedition, the specimen was collected in 1792 at Recherche Bay, Southern Tasmania, and Australia. The present investigation of anemone starfish fungus of Aseroe rubra is deep within the Western Ghats of Kalakad Mundanthurai Tiger Reserve Forest in the Tirunelveli District, TamilNadu, India.

Colour

A soft, hollow, columnar stalk will appear, and at the top, 3-4 inches above the ground, the reproductive portion will split open into 5-10 elongated arms, each of which will branch. The arms and "tentacles" are generally bright red or orange, and they give this organism the look of a starfish, or to my way of thinking, a seaanemone. The center of the red surface often shows an opening, and eventually a dark, oozing, slimy, messy, mass will appear. These fungi produce a dark brown to black slime containing spores on their surface, which has an intense smell of rotting meat or sewage. They are very common on wood or bark-chip mulch in gardens, and on deep litter on the rainforest floor. There are a number of differently shaped species, but all are readily recognizable by the smell of the spore slime.

Systematics

- Domain: Eukarya.

- $\quad$ Kingdom: Fungi.
- Phylum: Basidiomycota

- $\quad$ Class: Agaricomycetes.

- Order: Phallales.

- Family: Phallaceae.

- Genus: Aseroe.

- $\quad$ Species: rubra Labill., Bull. Murith. Soc. Valais. Sci. Nat. 1: 145 (1800).

- $\quad$ Daring, 1980 [1]

- $\quad$ Saenz and Nassar, 1982 [4].

- $\quad$ Calonge., et al. 2005a [3].

- $\quad$ Calonge and Mata, 2006 [2].

\section{Medical Properties}

Domestic dogs and cats are easy identifying for the smell. Deaths of small dogs have occurred. The toxins are unknown; during the developing stage is enzymatic liquefaction of the spore slime. In general gastro-irritants.

Note

Potentially toxic, depending on the level of exposure. Should not be grown in preschools, playgrounds, child care settings, and access should be restricted in homes with toddlers or young children (including homes where young children may visit, ie grandparents). Exclusion (such as fencing) from children's play areas is recommended. Parents and cares should supervise carefully (Figure 1). 


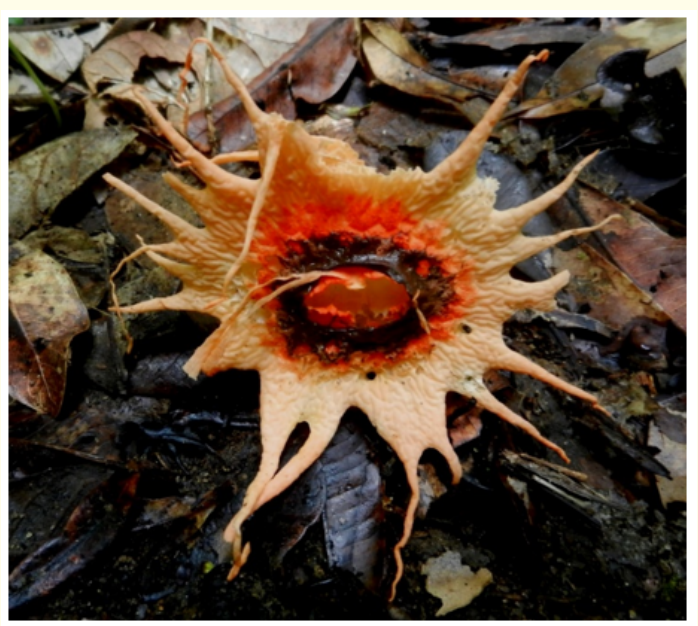

Figure 1: Aseroe rubra (Jacques Labillaridiere, 1755-1834).

\section{Bibliography}

1. Daring DM. "Contributions towards a rational arrangement of the Clathraceae". Kew Bulletin 35 (1980): 1-96.

2. Calonge FD and M Mata. "Adicionesy correcciones al catalogo de Gasteromycetes de Costa Rica". Boletín de la Sociedad Micológica de Madrid 30 (2006): 111-119.

3. Calonge FD. "Contribucion al catalogo de los Gasteromycetes (Basidiomycotina, Fungi) de Costa Rica". Anales del Jardín Botánico de Madrid 62.1(2005a): 23-45.

4. Saenz JA and M Nassar. "Hongos de Costa Rica: Famiilias Phallaceae Clathracead". Revista de Biología Tropical 30 (1982): 41-52.

Volume 2 Issue 12 December 2019

(C) All rights are reserved by Vaitheeswaran Thiruvengadam and M Anand Kumar. 